\title{
Mapeamento geomorfológico de detalhe em uma parcela do Quilombo Águas Claras - Triunfo/PE
}

\section{Detailed Geomorphological mapping in a land plot of Quilombo Aguas Claras - Triunfo/PE}

\author{
LIMA $^{1}$, G. R. de; SILVA ${ }^{2}$, Victor A. R.; MELO ${ }^{3}$, Luan V. O. \\ gibsongbmarl@gmail.com;
}

\begin{abstract}
Resumo
Um mapeamento geomorfológico de detalhe foi realizado no Quilombo Águas Claras, situado no município de Triunfo-PE. A área é considerada um brejo de altitude, onde a vegetação típica de caatinga do semiárido nordestino dá lugar a uma floresta subcaducifólia, ora em grande escala substituída por cultivos de subsistência. Uma metodologia de mapeamento foi aplicada a área, a fim de obter uma análise qualitativa dos processos superficiais em pequenas parcelas, além de reproduzir micro-formas da paisagem tais como, as rupturas de encosta e a cobertura da terra. A pesquisa de campo foi realizada numa parcela de $50 \mathrm{mx} 40 \mathrm{~m}\left(2.000 \mathrm{~m}^{2}\right)$, subdividida em células de $10 \mathrm{mx} 10 \mathrm{~m}$. Foram elaborados mapas: geomorfológico de detalhe, altitude, cobertura da terra e escoamento superficial. O intuito final do trabalho foi obter um registro gráfico de detalhe da morfologia e estrutura superficial de uma parcela.
\end{abstract}

Palavras-chave: mapeamento geomorfológico, cobertura da terra, Processos superficiais.

\begin{abstract}
A detailed geomorphological mapping was carried out at Quilombo Aguas Claras, located in the municipality of Triunfo-PE. The area is considered a highland montane environment, where the typical vegetation of caatinga of the semiarid Northeast region gives way to a semideciduous forest, largely replaced by subsistence crops. A detailed mapping methodology was applied to the area in order to obtain a qualitative analysis of surface processes in small land plots, and depict landscape microforms such as a breaks in slope and land-cover. The field research was carried out on a $50 \mathrm{mx} 40 \mathrm{~m}(2.000 \mathrm{~m} 2)$ land plot, subdivided into $10 \mathrm{mx} 10 \mathrm{~m}$ cells. The following types of maps were drawn: detailed geomorphology, topography, land-cover and surface runoff. The ultimate aim of the study was to obtain a detailed graphic record of the morphology and surface structure of a land plot
\end{abstract}

Keywords: Hillslope, Land-cover, surface Processes.

\section{INTRODUÇÃO}

No âmbito do estudo do revelo e da evolução da paisagem em regiões úmidas e semiúmidas com uma altitude acima de 1.000 metros n0o semiárido do Nordeste brasileiro, desenvolveu-se o mapeamento de uma área de encosta coluvial, com vistas a subsidiar a compreensão do seu desenvolvimento e como a população local utiliza esse tipo de feição geomorfológica da paisagem, tendo em vista que a principal atividade econômica da população local é a agricultura de subsistência. De acordo com Thomas (1994), os colúvios recobrem mais da metade das superfícies úmidas, subúmidas e secas dos trópicos, estando localizados preferencialmente na média e baixa encosta. O colúvio (colluvium) constitui o material heterogêneo e incoerente formado por solo e 
fragmentos de rocha depositados através de enxurradas ou deslizamentos, no sopé das encostas ou preenchendo depressões da topografia, no qual os movimentos de massa foram importantes agentes em sua deposição (Mousinho e Bigarella, 1965).

As regiões de altitude elevada, circunscritas pelo trópico semiárido do Nordeste do Brasil, como a área de estudo, são chamadas de Brejo de Altitude, e se caracterizam do ponto de vista geomorfológico por apresentarem encostas com recobrimento coluvial. Desta forma, o trabalho em tela foi desenvolvido sobre encostas coluviais que se caracterizam, segundo (Corrêa et al., 2008) como um depósito sedimentar que se acumula ao longo de uma encosta em consequência do transporte gravitacional, a despeito do conteúdo original de água nesses materiais. Visando compreender a evolução desse tipo de paisagem, foi analisada a cobertura da terra como um fator importante para dinamizar os processos que estão atuando sobre o modelado e qual a sua intensidade.

Vários são os processos que influenciam na evolução da paisagem e no desenvolvimento de uma encosta. De forma efetiva, esses processos são controlados pela litologia, cobertura vegetal e da terra, disponibilidade para transporte de partículas de solo e rocha, comprimento, declividade e forma de encosta (Selby, 1994). Os depósitos de encosta, segundo Selby (1994) e Bertran \& Texier (1994), estão em geral relacionados a processos como escoamento superficial (laminar e concentrado), ravinamento, voçorocamento e movimentos de massa. De acordo com Morgan (1986), o fluxo superficial hortoniano, junto com o destacamento de partículas do solo pelo impacto das gotas de chuva (splash), é responsável por cerca de 95\% da perda do solo em áreas de solo nu ou cultivado. Esse processo ocorre somente quando o índice de precipitação excede a capacidade de infiltração do solo (Morgan, 1986). Existem também outros processos que atuam para que ocorram mudanças nas paisagens das encostas e perda de solo, são eles: o fluxo subsuperficial, queda de blocos e fluxos de detritos.

Segundo Selby (1994), o fluxo subsuperficial e em túneis são responsáveis por pequenas quantidades de descarga de sedimentos para fora das encostas, sobretudo em sua base. Já a queda de blocos é um processo constituído por blocos que se soltam de lugares mais altos e de inclinações mais elevadas decorrente de algum tipo de erosão seja física ou química. Por fim, os fluxos de detritos constituem o fluxo de sedimentos liquefeitos oriundos da remoção de material acumulado em voçorocas ou de deslizamentos acrescidos de água (Bertran e Texier, 1999), compostos por uma mistura de solos, fragmentos de rochas e água.

Como visto acima não há como falar do relevo, evolução da paisagem e desenvolvimento de uma encosta sem aludir aos processos morfodinâmicos e à frequência dos mecanismos morfogenéticos. Neste sentido, optou-se por utilizar o conceito "bio-resistásico" proposto por Erhart 
(1956), no qual o autor trata de estágios morfopedogênicos diferenciados, associados a condições climáticas desencadeadoras distintas. Assim, na vigência da biostasia, a vertente encontra-se revestida de cobertura vegetal (propriedade geoecológica), enquanto que na resistasia a vertente encontra-se desprovida de cobertura vegetal, o que intensifica os processos superficiais. Pode-se falar ainda de antropo-resistasia que se caracteriza pela intensificação dos processos erosivos quando o homem influencia e modifica com suas ações as formas de cobertura da terra, sobretudo por remoção da vegetação nativa.

\section{METODOLOGIA}

Com o intuito de realizar um mapeamento geomorfológico de detalhe da área de estudo foi aplicada a metodologia de levantamento expedito em campo proposta por Corrêa e Azambuja (2005). A aquisição de dados foi realizada por meio do uso de um receptor de GPS e-Trex, que forneceu as coordenadas geográficas e elevação dos pontos de observação, programas como o Bubble-level e Altimeter, também foram utilizados com vistas a aferir a declividade dos segmentos da encosta e elevação, respectivamente.

A parcela de estudo escolhida para realização do mapeamento conta com uma área de $2.000 \mathrm{~m}^{2}$ (dois mil). Para fins de observação, descrição e mensuração das propriedades superficiais, a mesma foi dividida em 20 células, cada uma medindo $100 \mathrm{~m}^{2}$. As células foram analisadas de acordo com o nível de equilíbrio morfodinâmico para cada das seguintes categoria: cobertura da terra, vegetação e ocorrência de processos superficiais. A vulnerabilidade ecodinâmica foi avaliada qualitativamente para cada célula por meio da atribuição de um índice cujos valores variaram de 1 (estável) para 3 (fortemente instável). Um arquivo em forma de matriz foi gerado para cada categoria observada. Na planilha eletrônica foram tabuladas as coordenadas UTM e o valor do índice morfodinâmico, o que permitiu a geração de um mapa de isovalores de vulnerabilidade à erosão. Para a construção do mapa, o arquivo com a planilha eletrônica foi convertido em linhas de isovalores por meio do uso de interpoladores do software Surfer8.

O trabalho de campo foi realizado entre os dias 23 e 27 de maio de 2016, como parte da disciplina em Geomorfologia Climática, oferecida pela graduação em Geografia Bacharelado da Universidade Federal de Pernambuco. A parcela de estudo aqui considerada foi uma área, do

Quilombo Águas Claras, situado no município de Triunfo, Estado de Pernambuco, sendo seus pontos extremos definidos pelas seguintes coordenadas UTM: 602864, 602907, 602863, 602902 / S e 9136917, 9136913, 9136861, 9136867 / W. Com a obtenção dos dados, um mapa geomorfológico de detalhe foi produzido baseado no levantamento direto de campo das feições do relevo. Estes 
procedimentos demandaram o uso de um GPS, programas para medir declividade e elevação, além de trena de 30 metros e câmera digital.

Após o levantamento de campo, os dados foram organizados em softwares de interpolação, mapeamento e editoração gráfica, a saber: Surfer8 e Power Point. Pelo uso do Surfer8, as informações relativas ao grau de vulnerabilidade ecodinâmica na parcela de estudo foram convertidas em mapas com linhas de contorno de isovalores. Assim, o mapa de isovalor foi comparado ao mapa de uso do solo a fim de confrontar a consistência da informação, bem como, verificar o equilíbrio do solo no tocante aos processos de biostasia, resistasia e antroporesistasia.

\section{RESULTADOS E DISCUSSÃO}

De acordo com os dados obtidos na área estudada no Quilombo Águas Claras/Triunfo-Pe, foi possível observar a partir do mapa de cobertura da terra (Figura 1), que mesmo com a presença de pouca vegetação arbórea e herbácea nativa remanescente, a predominância da lavoura (cultivo de banana) conduziu a área a um grau antropogênico de equilíbrio biostásico, como mostra o mapa de unidades ecodinâmicas (Figura 2).

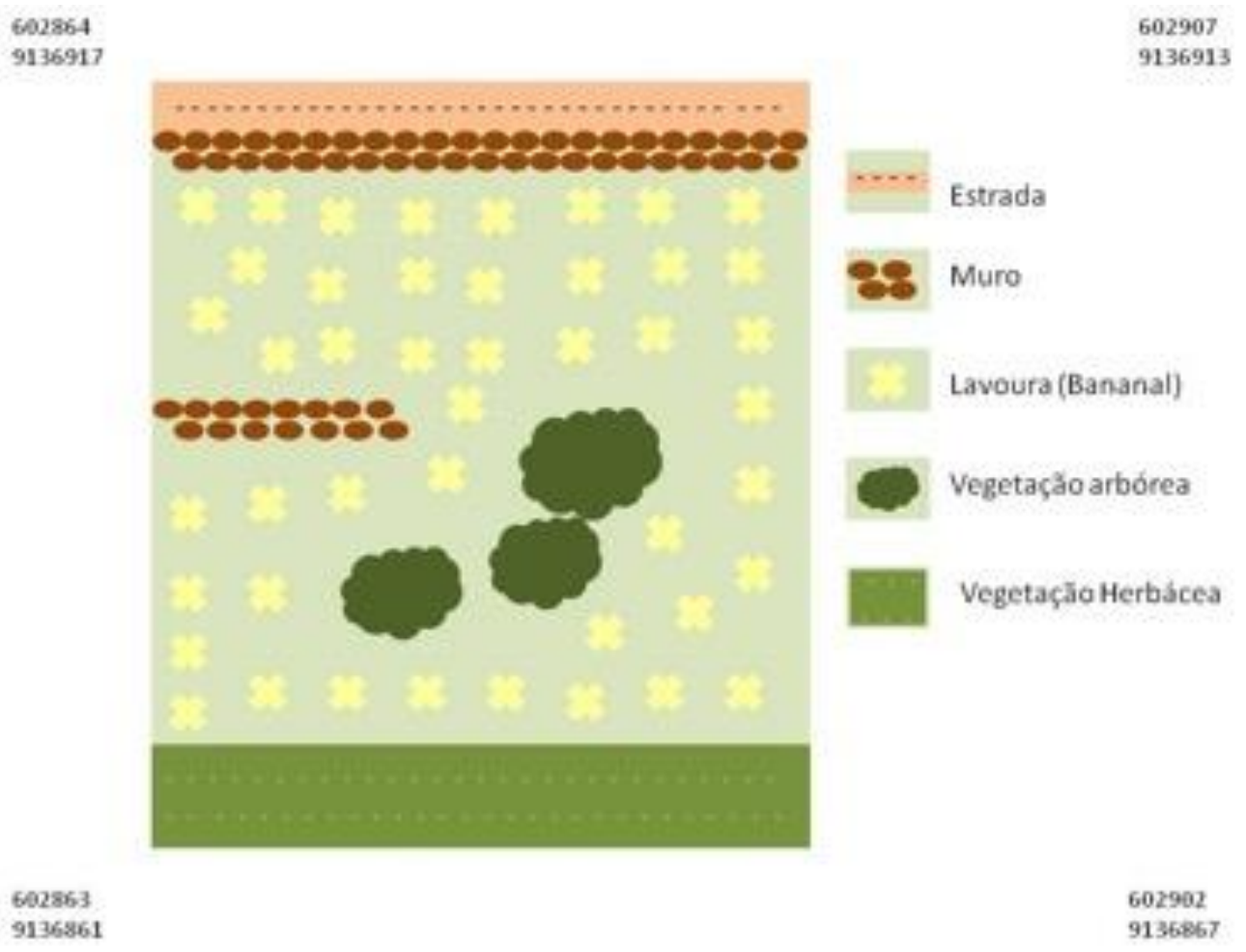

Figura 1 - Mapa de cobertura da terra 


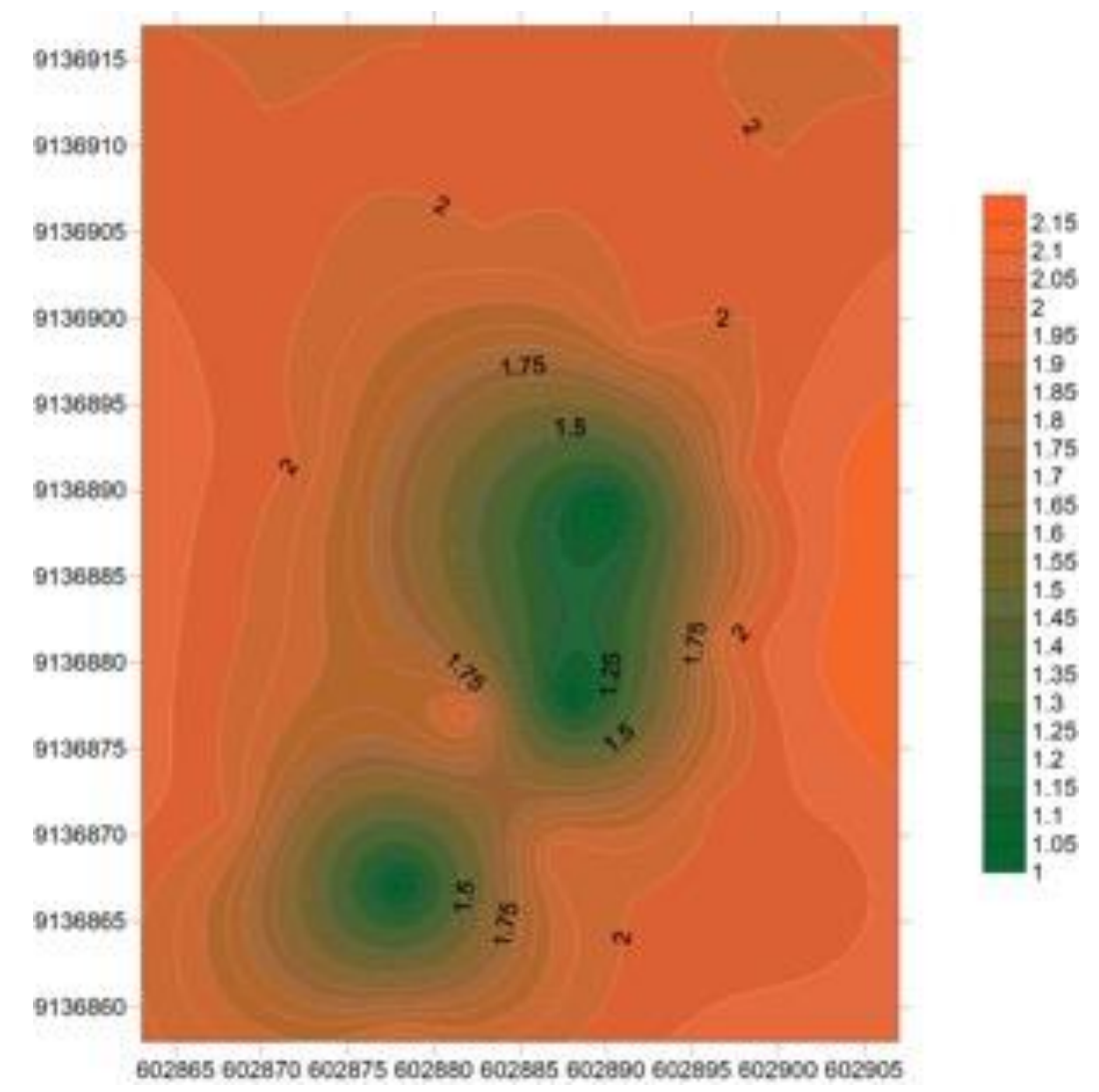

Figura 2 - Mapa Vulnerabilidade Ecodinâmica

A fim de obter os dados para a confecção do mapa geomorfológico de detalhe (Figura 3), inicialmente observou-se em campo a cobertura superficial da paisagem, elevação, declividade e escoamento superficial (Figura 5), em cada uma das 20 células de análise. Quanto à formação do depósito coluvial, as observações de campo permitiram verificar que a deposição de sedimentos se deu através de um fluxo não canalizado, relacionado a antigos movimentos gravitacionais, do tipo corrida de lama. A medição dos parâmetros morfométricos da encosta possibilitou definir que a mesma é marcada por duas rupturas de gradiente, caracterizando uma encosta separada por knickpoints. A área mapeada possui um gradiente altimétrico entre 1028m e 1064m (Figura 4), e uma declividade variando entre $5^{\circ}$ e $11^{\circ}$. Observou-se também a falta de evidências da ação da erosão linear seja em sulcos, ravinas e voçorocas, não obstante, a falta de vegetação arbórea, como também a prática do cultivo de banana, tem favorecido a ocorrência de erosão laminar em alguns setores e infiltração em outros, esta última pode vir a resultar na ocorrência de pipings na base da encosta por erosão sub-superficial. 
602864

9136917

602863

9136861
602507

9136913
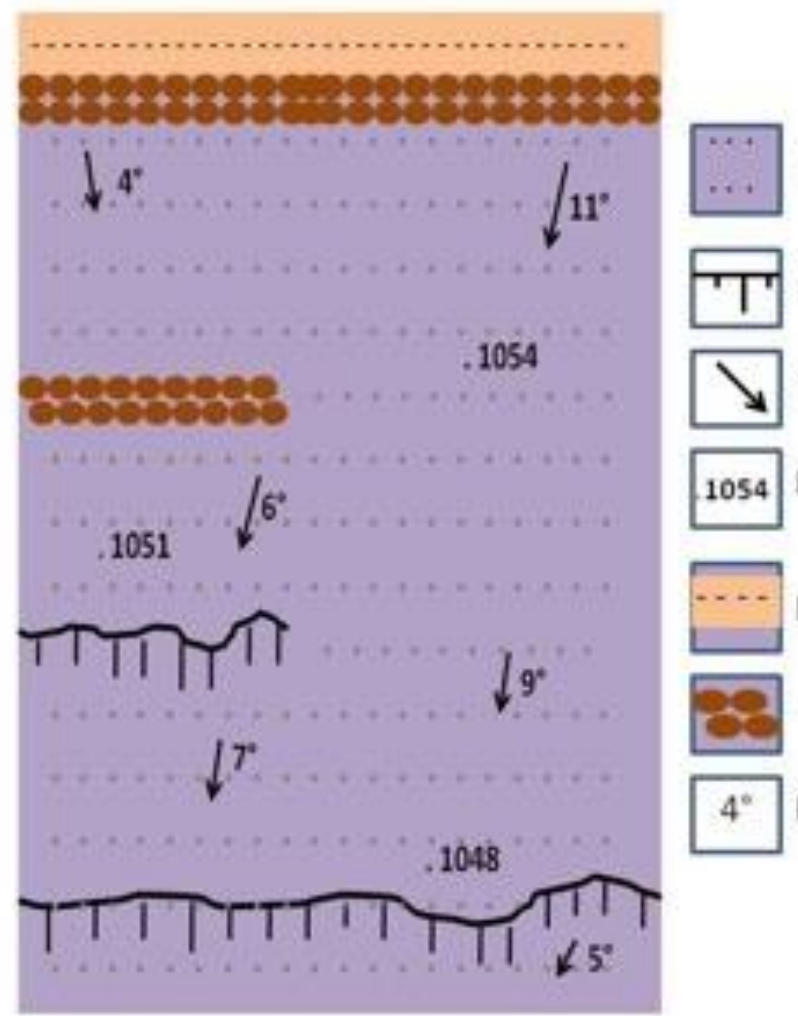

Encosta Coluvial

TT Ruptura de Gradiente

$\searrow$ Sentido do fluxo superficial

1054 Ponto Cotado

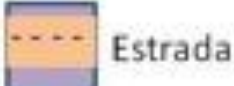

Muro

$4^{\circ}$ Declividade

602902

9136867

Figura 3 - Mapa geomorfológico de detalhe

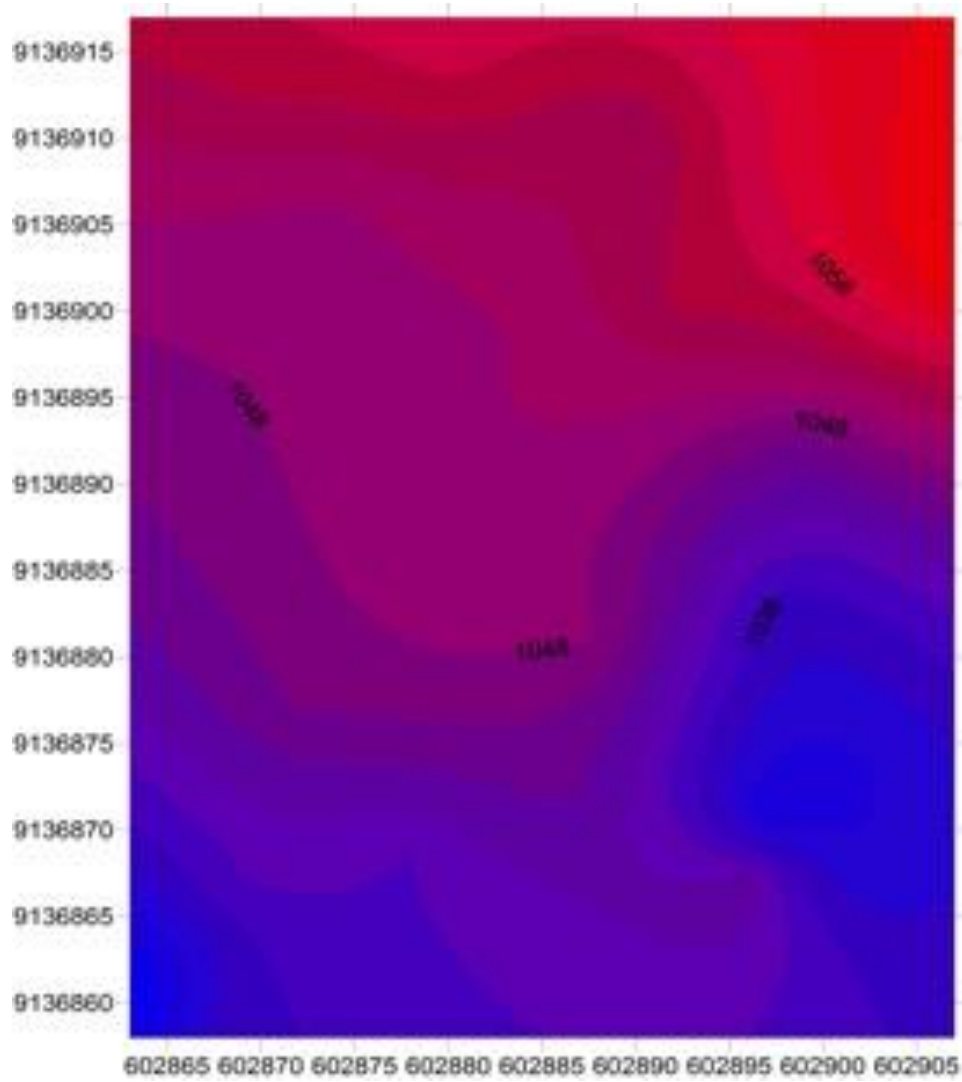

Figura 4 - Mapa topográfico 


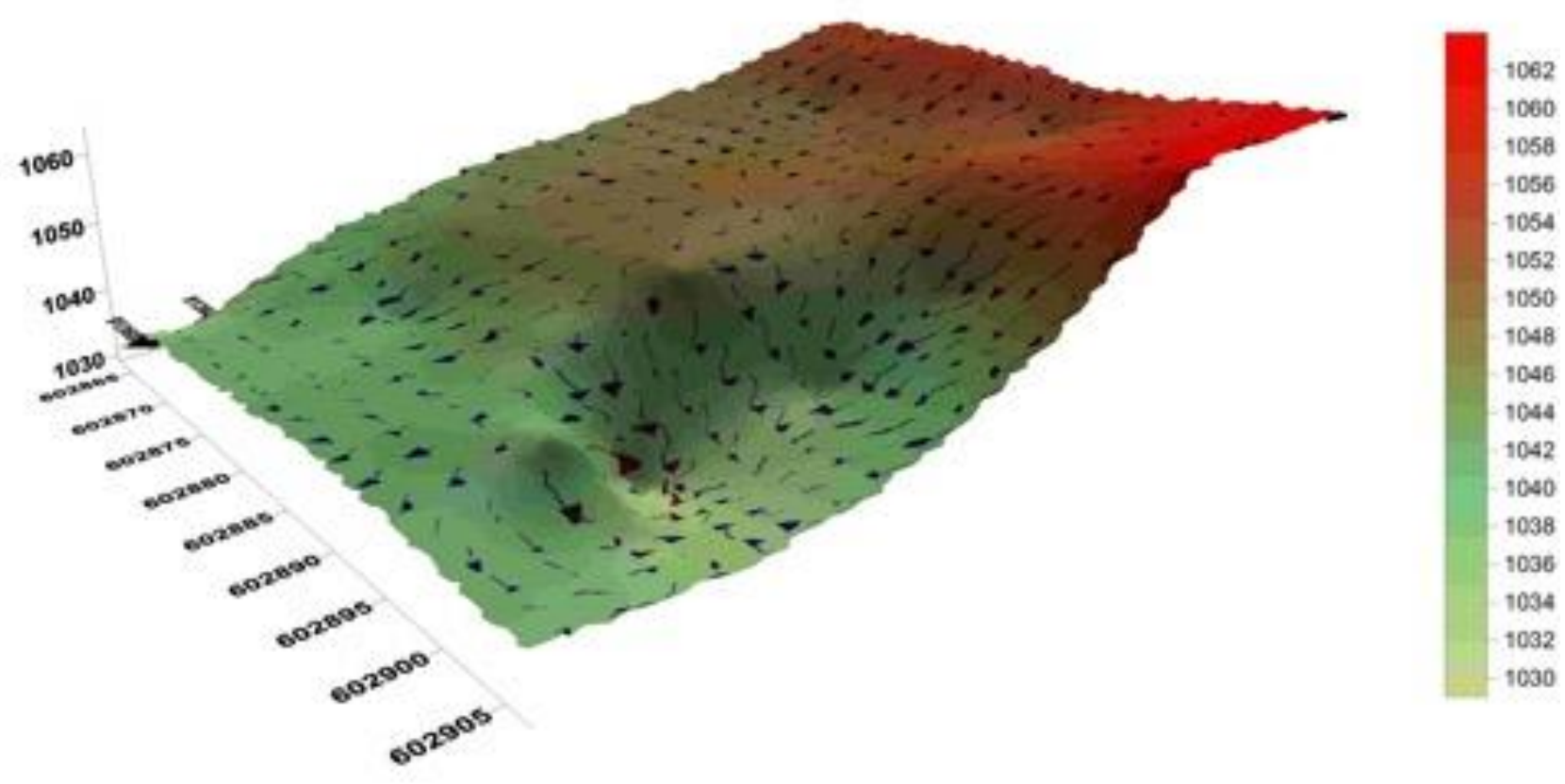

Figura 5 - MDT com indicação do Escoamento Superficial

Entende-se que, na área estudada, as práticas locais de uso da terra também favorecem a erosão, sobretudo os processos laminares, uma vez que a população local utiliza-se da encosta de até $11^{\circ}$ de declividade para o cultivo de banana, milho, etc. Cruzando as observações realizadas in situ e os dados de mapeamento, foi possível aferir a relativa inadequação das condições geomorfológicas locais a determinados tipos de uso. Quanto à cobertura vegetal observou-se que os elementos arbóreos foram quase que completamente substituídos por exóticas como a Mangueira (Mangifera Indica), porém a vegetação herbácea nativa ainda desempenha um papel relevante no tocante à relação entre a cobertura da terra e o equilíbrio biostásico da parcela. 


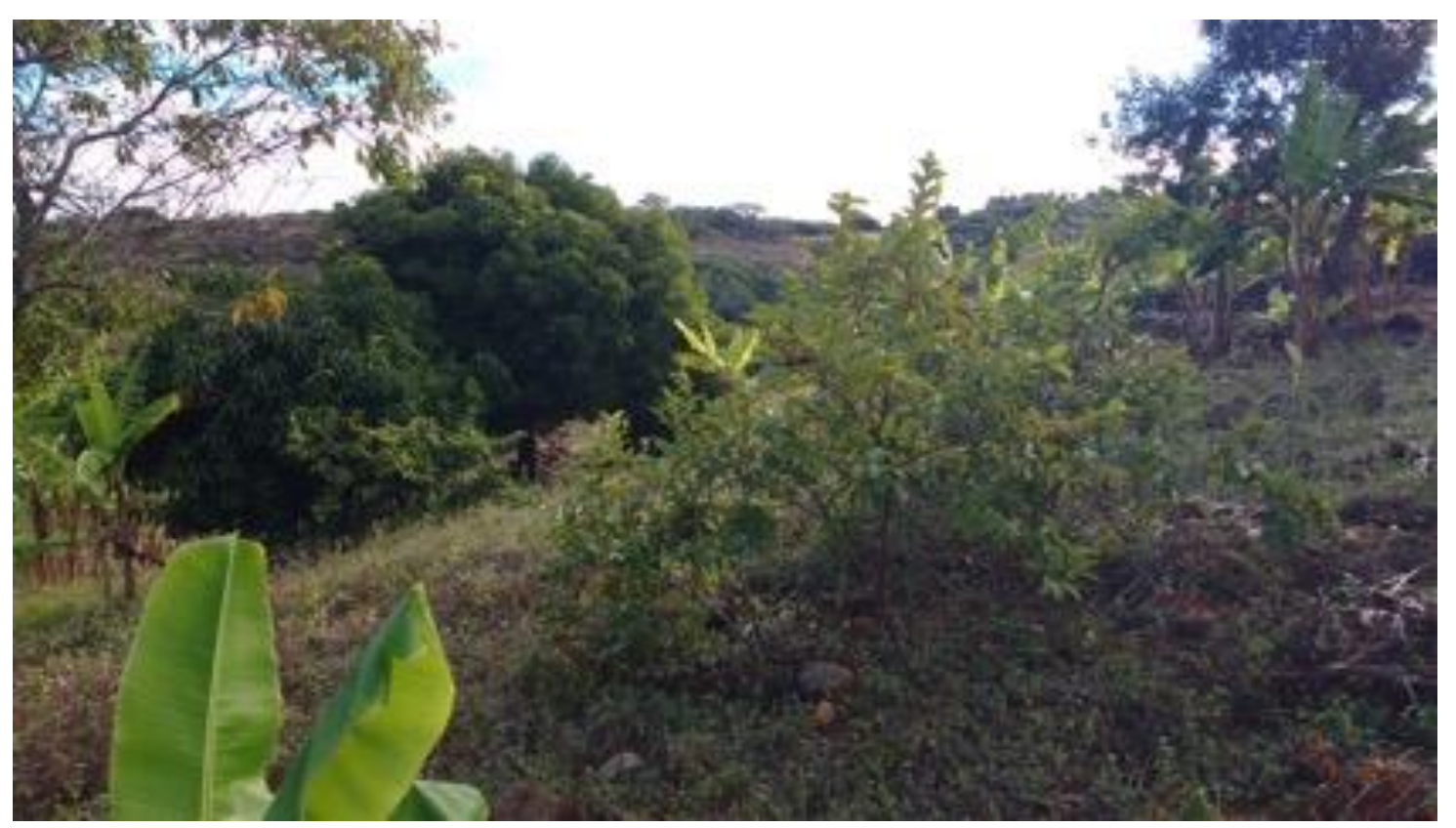

Figura 6 - Evidência de vegetação arbórea exotica

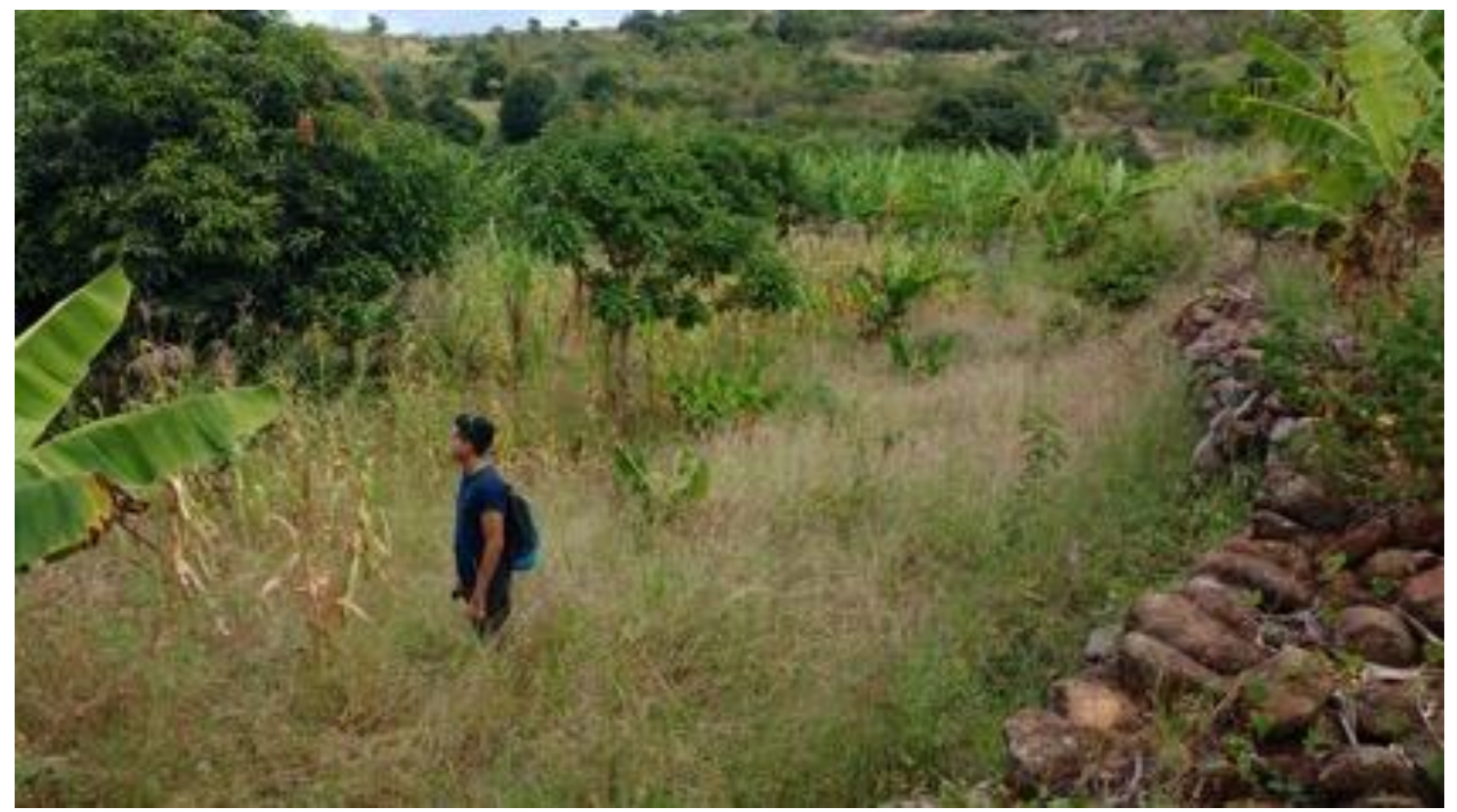

Figura 7 - Evidência de vegetação herbácea e muro construído sob uma ruptura de gradiente

\section{CONSIDERAÇÕES FINAIS}

A técnica aplicada de mapeamento geomorfológico de detalhe e construção de mapa de linhas de isovalores, com observação direta dos fatos geomorfológicos no campo e tratamento dos dados morfodinâmicos em planilha eletrônica e interpolador espacial, permitiu evidenciar que a metodologia foi bem sucedida para os fins desejados, constituindo assim uma ferramenta rápida e bastante eficaz para a avaliação dos processos superficiais, cobertura da terra, dinâmica da cobertura superficial da paisagem, bem como a estabilidade ambiental em pequenas parcelas. A 
dinâmica de superfície no contexto morfoclimático dos brejos de altitude do Nordeste do Brasil foi elucidada de forma clara, havendo o mapeamento demonstrado a existência de uma encosta coluvial separada por rupturas de gradiente, posteriormente utilizadas para a implementação de estruturas de conservação dos solos coluviais, conforme se observa na figura 07 sob a forma de muretas de pedras.

Na parcela mapeada, ficou evidente que apesar das transformações implementadas pelos cultivos, o equilíbrio biostásico vem se mantendo, ainda que o uso da terra seja voltado para o cultivo de bananas, devido à relevante quantidade de vegetação herbácea, inclusive as próprias bananeiras. No tocante aos processos superficiais, observou-se que os movimentos de massa tiveram papel essencial para a formação do colúvio na evolução da encosta na escala do holoceno, porém, devido ao uso da terra pelos cultivos, outros processos erosivos tem contribuído para a gradativa perda do solo na encosta, mormente a erosão liminar e sub-superficial, necessitando assim que práticas conservacionistas sejam implementadas não apenas nesta parcela, mas em outros contextos similares dos brejos de altitude do Nordeste do Brasil.

\section{REFERÊNCIAS}

BERTRAN P, TEXIER JP. Structures sedimentaires dans un cone de flots de debris (Vars, Alpes franc, aises me' ridionales). Permafrost and Periglacial Processes, n. 5, p.155-170, 1994.

CORRÊA, A. C. B.; SILVA, D. G. da.; MELO, J. S. Utilização dos depósitos de encostas dos brejos pernambucanos como marcadores paleoclimáticos do quaternário tardio no semi-árido nordestino. Mercator, n. 14, p. 99-125, 2008.

CORRÊA,A.C.B.;AZAMBUJA,R.N. Avaliação qualitativa em micro-escala da estabilidade da paisagem em áreas sujeitas a desertificação no ambiente semi-árido do Nordeste Brasileiro, Anais do XI Simpósio brasileiro de geografia física aplicada, p.5839-5847, 2005.

BERTRAN, P.; TEXIER, J. P. Facies and microfacies of slope deposits. Catena, v. 35, p. 99-121, 1999.

Erhart, H. La theorie bio-rexistesique et les problemews biogeographiques et paleobiologiques. Soc. Biogeogr., France, CNR (288):43-53, 1956.

MOUSINHO, M. R.; BIGARELLA, J. J. Movimentos de massa no transporte dos detritos da metorização das rochas. Boletim Paranaense de Geografia. CURITIBA, n. 16/17, p. 43-84, 1965.

SELBY, M. J. Hillslope sediment transport and deposition. In: PYE, K. (Ed.) Sediment transport and depositional processes. London: Blackwell Scientific Publications, 1994.

THOMAS, M. F. Geomorphology in the tropics: a study of weathering and denudation in low latitudes. Jhon Whiley \& Sons Ed. Winchester, England, 1994. 


\section{AGRADECIMENTOS}

Primeiramente a Deus que permitiu que tudo isso acontecesse, ao longo de nossas vidas, e não somente nestes anos como universitários, mas que em todos os momentos é o maior mestre que alguém pode conhecer.

A Universidade Federal de Pernambuco pela oportunidade de fazer o curso, ao Departamento de Geografia junto com o Laboratório de pesquisa GEQUA (Grupo de Estudos do Quaternário do Nordeste Brasileiro) por proporcionar o campo de pesquisa e estudos.

Ao Prof. Dr. Antônio Carlos de Barros Corrêa pela oportunidade e apoio na elaboração deste trabalho.

Recebido em: 14/08/2016

Aceito para publicação em: 01/10/2016 